\title{
梁ウェブ接合部分を補強した鋼構造柱梁接合部の力学性能に関する実験的研究 EXPERIMENTAL STUDY ON EFFECT OF REINFORCEMENTS AT WEB CONNECTED PARTS OF WF BEAM TO SHS COLUMN CONNECTIONS
}

\author{
中野達也*, 増田浩志**, 田中淳夫*** \\ Tatsuya NAKANO, Hiroshi MASUDA and Atsuo TANAKA
}

\begin{abstract}
In this paper, the static characteristics of WF beam to SHS column connections that beam web connected parts were reinforced were investigated by cyclic loading test. The methods of reinforcement were inserting horizontal diaphragm or vertical stiffener inside panel zone. The main' parameters were type of reinforcements, width-to-thickness ratio of the column and type of web connection. The test results shows that by reinforcing of web connected parts the maximum strength and the plastic deformation ability of the beam-to-column connection are getting better. The reasons are that the out-of-plane deformation of the column is restrained enough and the bending moment carrying ratio of web connected parts becomes large by reinforcement.
\end{abstract}

\section{Keywords : beam-to-column connection, reinforcement of web connected parts, out-of-plane deformation of column', horizontal diaphragm, vertical stiffener 柱梁接合部, 梁ウェブ接合部分の補強, 柱の面外変形, 水平ダイアフラム, 縦スチフナ}

\section{1.はじめに}

鋼構造建築物の箱形断面柱とH形断面梁を用いた柱梁接合部にお いて、梁全体の曲げモーメントは梁フランジ接合部分と梁ウェブ接 合部分の両方で負担される。このうち、梁ウェブ接合部分の負担す る曲げは梁ウェブが取付く柱スキンプレートの面外曲げ挙動に大き く依存することが多くの研究により報告されている11-5)。また、梁 ウェブ接合部分の負担曲げ耐力が接合部全体の最大曲げ耐力と接合 される梁の塑性変形能力（以下、「塑性変形能力」と表記）に大きな 影響を与えることから、柱スキンプレートの面外剛性を十分に確保 する必要があることが指摘されている6) 9)。この点は梁ウェブ接合 部分を高力ボル卜摩擦接合とする、いわゆる梁端混用接合部におい て特に問題となり、筆者等は主としてこの形式の柱梁接合部を対象 とした研究を行ってきた6) 8)。しかし、実際の設計では柱の幅厚比 の制限は設けられているものの、それは柱部材の局部座屈防止の観 点から定められているため柱梁接合部における柱スキンプレートの 面外剛性を十分確保するものではなく、柱の幅厚比が比較的大きな ものも使用されているのが現状である.10)。

これらのことから、筆者らは梁端混用接合部に関して箱形断面柱 の梁ウェブとの接合部分における面外剛性を確保するために、梁 ウェブ取付け位置の柱内部における数種類の補強工法を提案し、そ の効果を実験的に検討した11)。その結果から：梁ウエブ接合部分の
補強による接合部全体の力学性能の向上を確認することができたが、 その研究では製作方法が特殊な柱材を用いた試験体が大半を占め柱 の幅厚比も比較的小さいものであったため、実際に多く用いられて いる一般的な冷間成形角形鋼管を用いた柱材における梁ウェブ接合 部分の補強効果を十分確認できていない。さらに、柱スキンプレー トの面外剛性が接合部全体の力学性能及び梁の崩壊形式に与える影 響については未だ不明な点が多く、それらを定量的に評価するまで には至っていない。

そこで本研究では、上述の点に関連した基礎資料の蓄積を図るた めに、柱梁接合部における梁ウェブ接合部分の補強効果及び柱の幅 厚比の影響を把握することを目的として実大加力実験を行った。梁 ウェブ接合部分における補強方法は梁ウェブの取付く柱内部に補強 板を挿入するもので、水平ダイアフラム補強形式と縦スチフナ補強 形式の 2 種類である。本報は実験に基づいて、梁ウェブ接合部分の 補強形式, 柱の幅厚比, 梁端接合形式及び梁材の鋼種の違いが接合 部全体の耐力, 塑性変形能力, 梁端近傍の歪分布に与える影響につ いて唡討を行うものである。

\section{2. 実験概要}

\section{1 試験体計画}

試験体の形状及び加力状況を図 1 に示す。試験体は逆 T字型の部
* 宇都宮大学工学部建設学科 助手・博士 (工学)

** 宇都宮大学工学部建設学科 助教授・博士 (工学)

*** 東京電機大学工学部建筑学科 教授・工博
Research Assoc., Dept: of Architecture and Civil Eng., Faculty of Eng., Utsunomiya Univ., Dr. Eng.

Assoc. Prof., Dept. of Architecture and Civil Eng., Faculty of Eng., Utsunomiya Univ., Dr. Eng.

Prof., Dept. of Architecture, Faculty of. Eng., Tokyo Denki Univ., Dr. Eng. 


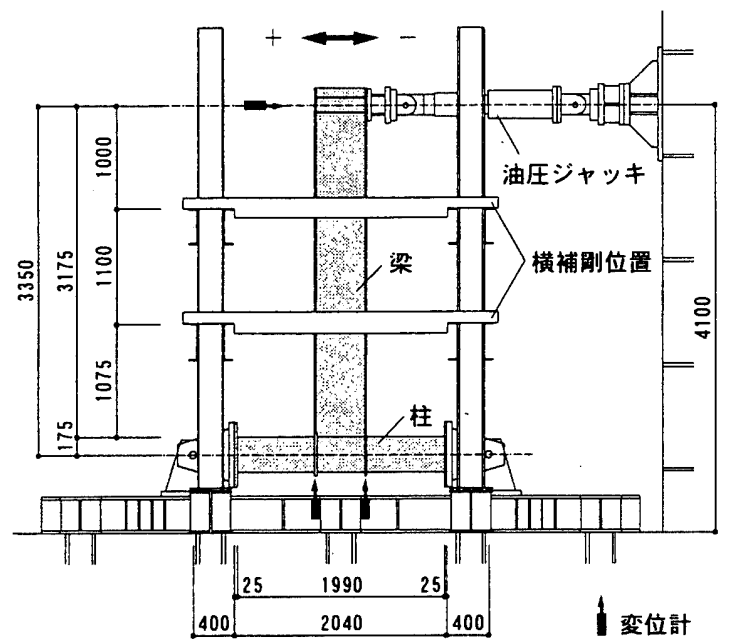

図 1 試験体形状及び加力状況

分骨組架構とし、柱端部をピン支持とした。試験体リストを 表 1 に、各試験体の柱梁接合部の詳細を図 2-4 に示す。梁端 部の接合形式は、梁ウェブ接合部分を隅肉溶接とした全溶接 接合形式（W）と、この部分を高力ボルト摩擦接合とした混 用接合形式 (B) の 2 種類とした。梁材は全て $500 \times 200 \times 10 \times 16$ のH形鋼で、W シリーズにはSS400 材を、Bシリーズには SN400B 材を用いた。柱材は全て $350 \mathrm{~mm}$ 角の冷間成形角形鋼 管BCR295 材で、板厚 $19 \mathrm{~mm}$ の通しダイアフラム形式とした。 柱の板厚はWシリーズでは $9 \mathrm{~mm}, 12 \mathrm{~mm}, 16 \mathrm{~mm} 、 B$ シリーズで は $12 \mathrm{~mm}, 16 \mathrm{~mm}$ とし、各試験体名の数字は柱の幅厚比 $\mathrm{D} / \mathrm{t}$ を表 している。梁ウェブ接合部分における補強方法は梁ウェブの 取付く柱内部に補強板を挿入するもので、上下 2 ケ所で各1枚 の水平ダイアフラムを完全溶込み溶接で柱内側面に取付ける 水平ダイアフラム補強形式（試験体名-HD）と、予め十字形 に組立てた縦スチフナを柱材軸方向のみ両面隅肉溶接で柱内 側面に取付ける縦スチフナ補強形式（試験体名-VS）である。補強 板の板厚は、HD, VS共に梁ウェブ板厚のワンサイズアップの $12 \mathrm{~mm}$ とした。また、これらの補強試験体との比較のために接合部パネル 部を無補強とした一般的な接合形式（試験体名-N）の試験体も加え た。梁端ディテールはスカラップ底のアールを $10 \mathrm{~mm}$ としたスカ ラップエ法とし、エンドタブには全試験体ともスチールタブを用い た。また、本研究では梁ウェブ接合部分に着目しているため、B シ リーズの試験体に関しても梁フランジとダイアフラムとの溶接をW シリーズの試験体と同様に上下とも外側から行った。

梁ウェブ接合部分の曲げ負担範囲は梁端接合部最大耐力評価式12) を用いて算定した。算定結果を表 2 に示す。補強試験体の曲げ負担 範囲はせん断力を負担する範囲を梁ウェブ有効成から除いた範囲と した。最大耐力の算定では、梁ウェブ溶接部の溶接金属の耐力には 引張強さを用いており、Bシリーズでは曲げ負担範囲において柱ス キンプレートの面外曲げ降伏による最大耐力 $\mathrm{c}_{\mathrm{wu}}$ より高力ボルト接 合部分の最大耐力。 $\mathrm{M}_{\mathrm{wu}}$ の方が大きくなるように計画した。補強試騃 体の設計法に関しては、HDの補強位置はW 補強試験体の曲げ負担 範囲内のほぼ真ん中とし、VSの成は柱とダイアフラム溶接部の裹当 て金を避けるように設計した。HDの補強板の板厚については、 $\mathrm{j} \mathrm{M}_{\mathrm{wu}}$ に対して一般的なダイアフラムの設計と同様の確認を行った。
表 1 試騒体リスト

\begin{tabular}{|c|c|c|c|c|c|}
\hline 試験体名 & $\begin{array}{c}\text { 柱板厚 } \\
(\mathrm{mm})\end{array}$ & 梁鋼種 & 接合形式 & 補強形式 & 載荷方法 \\
\hline W39-HD & \multirow{3}{*}{9} & \multirow{7}{*}{ SS400 } & \multirow{7}{*}{ 全溶接 } & 水平ダイアフラム & \multirow{11}{*}{ 漸增振幅 } \\
\hline W39-VS & & & & 縦スチフナ & \\
\hline W39-N & & & & 無補強 & \\
\hline W29-HD & \multirow{3}{*}{12} & & & 水平ダイアフラム & \\
\hline W29-VS & & & & 縦スチフナ & \\
\hline W29-N & & & & 無補強 & \\
\hline W22-N & 16 & & & 無補強 & \\
\hline B29-HD & \multirow{3}{*}{12} & \multirow{4}{*}{ SN400B } & \multirow{4}{*}{ 混用 } & 水平ダイアフラム & \\
\hline B29-VS & & & & 縦スチフナ & \\
\hline $\mathrm{B} 29-\mathrm{N}$ & & & & 無補強 & \\
\hline B22-N & 16 & & & 無補強 & \\
\hline W22-HD-R & \multirow{6}{*}{16} & \multirow{3}{*}{ SS 400} & \multirow{3}{*}{ 全溶接 } & 水平ダイアフラム & \multirow{6}{*}{ 一定振幅 } \\
\hline W22-VS-R & & & & 縦スチフナ & \\
\hline W22-N-R & & & & 無補強 & \\
\hline B22-HD-R & & \multirow{3}{*}{ SN400B } & \multirow{3}{*}{ 混用 } & 水平ダイアフラム & \\
\hline B22-VS-R & & & & 縦スチフナ & \\
\hline B22-N-R & & & & 無補強 & \\
\hline
\end{tabular}

表 2 梁端接合部最大耐力計算値

\begin{tabular}{|c|r|r|r|r|r|r|r|}
\hline & $\begin{array}{c}\mathrm{X} \\
(\mathrm{mm})\end{array}$ & $\begin{array}{c}{ }_{\mathrm{c}} \mathrm{M}_{\mathrm{wu}} \\
(\mathrm{kNm})\end{array}$ & $\begin{array}{c}{ }_{\mathrm{b}} \mathrm{M}_{\mathrm{wu}} \\
(\mathrm{kNm})\end{array}$ & $\begin{array}{c}{ }_{\mathrm{j}} \mathrm{M}_{\mathrm{wu}} \\
(\mathrm{kNm})\end{array}$ & $\begin{array}{c}{ }^{j} \mathrm{M}_{\mathrm{fu}} \\
(\mathrm{kNm})\end{array}$ & $\begin{array}{c}{ }^{\mathrm{j}} \mathrm{M}_{\mathrm{u}} \\
(\mathrm{kNm})\end{array}$ & ${ }_{j} \mathrm{M}_{\mathrm{u}} / \mathrm{M}_{\mathrm{p}}$ \\
\hline W-HD,VS & 184 & 96 & - & 96 & 652 & 747 & 1.13 \\
\hline W39-N & 92 & 50 & - & 50 & 652 & 702 & 1.07 \\
\hline W29-N & 111 & 63 & - & 63 & 652 & 715 & 1.08 \\
\hline W22-N & 139 & 79 & - & 79 & 652 & 731 & 1.11 \\
\hline B-HD,VS & 202 & 129 & 161 & 129 & 678 & 806 & 1.28 \\
\hline B29-N & 117 & 80 & 95 & 80 & 678 & 757 & 1.20 \\
\hline B22-N & 142 & 100 & 111 & 100 & 678 & 778 & 1.24 \\
\hline
\end{tabular}

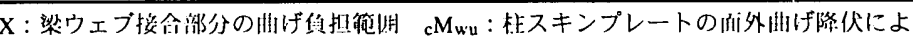

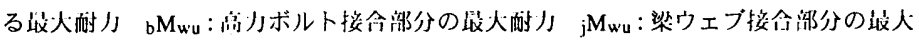

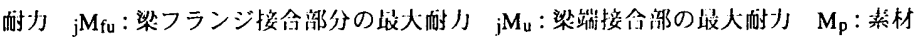

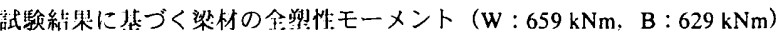

\section{2 鋼材の機械的性質}

実験に用いた各種鋼材に関して、試験体から切り出しだJS Z2201 $1 \mathrm{~A}$ 号試験片による引張試験の結果を表 3 に示し、JIS Z2202 Vノッ チシャルピー試験片による衝撃試験の結果を表4に示す。ここで、引 張試験結果に関して、柱材に用いた鋼材は応力ー歪関係において明 瞭な降伏点を示さなかったため、降伏応力度を0.2\%オフセット耐力 としている。梁材の降伏点及び降伏比はSS400 材に比べ SN400B 材 の方が小さな値を示している。シャルピー衝撃値に関しては、、 $\mathrm{E}_{0}$ の 值はSN400B材に比べSS400材の方が大きく、倦移温度もSN400B 材 に比べSS400 材の方が低い。しかし、載荷実験を行った常温での平 均値はいずれも $150 \mathrm{~J}$ 程度であり、その值も大きくかつ両諸の間にそ れほど大きな差は見られないため、本実験においては衝撃値の違い が接合部全体の力学性能に及ぼす影響は小さいと推測される。

\section{3 載荷方法}

載荷は、図 1 に示すように梁頂部に油圧ジャッキによる正負交番 繰返しの水平荷重を作用させるものであり、加力点に設埴した変位 計の読取り値による変位制御で行った。載荷履歴は漸增振幅繰返し 載荷（以下、「基本載荷」）と一定振幅繰返し載荷（以下、「 $\mathrm{R}$ 載荷」： 試験体名 -R）の 2 種類とした。基本載荷は梁材の公称値の 1.1 倍の 值に基づく全塑性モーメントに対応する梁部材のみの加力点におけ 

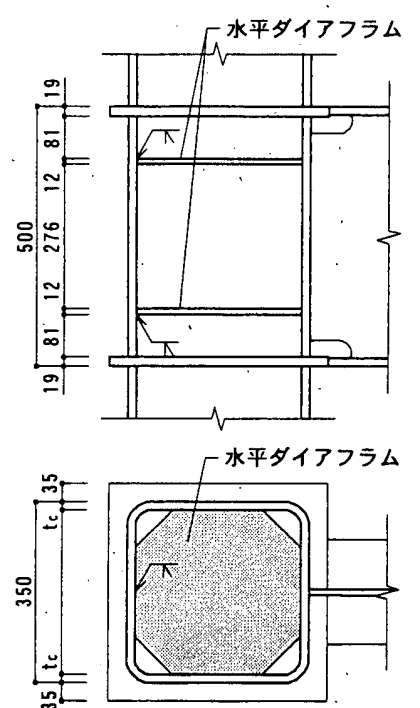

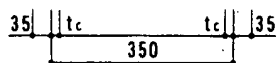

HDタイプ
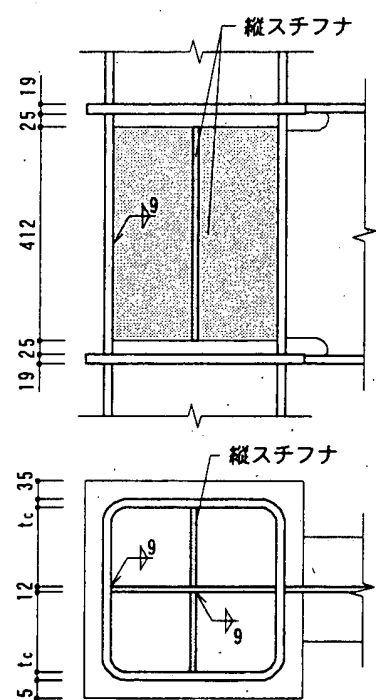

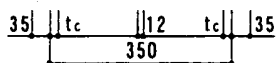

vsタイプ

2 柱梁接合部詳細
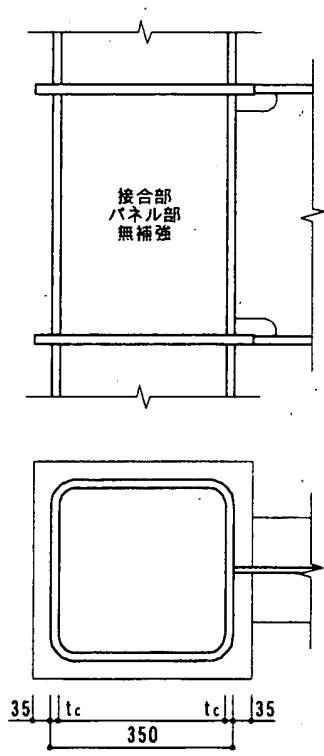

Nタイプ

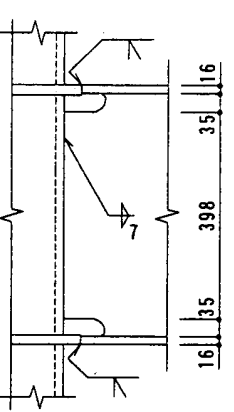

Wシリース

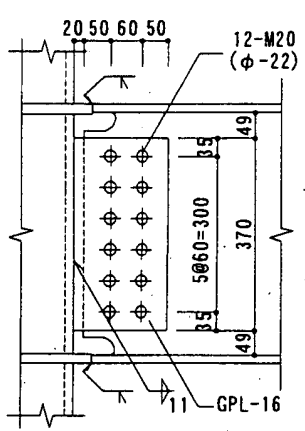

Bシリース

図 3 仕口部詳細

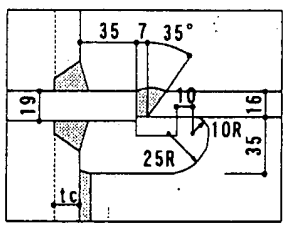

W シリース

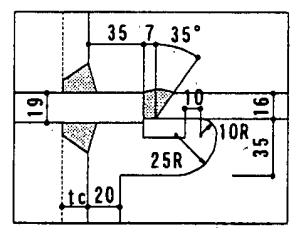

Bシリース

図 4 スカラップ詳細

表 3 鋼材の機械的性質

\begin{tabular}{|l|c|r|r|r|r|}
\hline \multicolumn{1}{|c|}{ 使用箅所 } & \multicolumn{1}{c|}{ 鋼種 } & $\begin{array}{c}\sigma_{y} \\
\left(\mathrm{~N} / \mathrm{mm}^{2}\right)\end{array}$ & $\begin{array}{c}\sigma_{u} \\
\left(\mathrm{~N} / \mathrm{mm}^{2}\right)\end{array}$ & $\begin{array}{c}\text { YR } \\
(\%)\end{array}$ & $\begin{array}{c}\mathrm{EL} \\
(\%)\end{array}$ \\
\hline W39柱 & $\mathrm{BCR} 295$ & 345 & 425 & 81.2 & 23.0 \\
\hline W29, B29柱 & $\mathrm{BCR} 295$ & 351 & 414 & 84.8 & 26.5 \\
\hline W22, B22柱 & $\mathrm{BCR} 295$ & 394 & 438 & 89.9 & 20.8 \\
\hline W梁ウェブ & SS400 & 362 & 451 & 80.3 & 23.2 \\
\hline B梁ウェブ & SN400B & 337 & 464 & 72.6 & 21.8 \\
\hline W梁フランジ & SS400 & 297 & 421 & 70.5 & 29.3 \\
\hline B梁フランジ & SN400B & 287 & 437 & 65.6 & 27.0 \\
\hline HD, VS補強材 & SS400 & 291 & 400 & 72.8 & 30.4 \\
\hline ダイアフラム & SN400B & 279 & 426 & 65.5 & 32.8 \\
\hline Bガセットプレート & SN400B & 279 & 424 & 65.7 & 31.2 \\
\hline
\end{tabular}

表 4 `シャルピー衝撃試験結果

\begin{tabular}{|c|c|c|c|c|c|c|}
\hline 鋼種 & 採取部分 & $\begin{array}{l}{ }_{v} E_{0} \\
\text { (J) }\end{array}$ & $\begin{array}{l}{ }_{v} E_{r} \\
\text { (J) }\end{array}$ & $\begin{array}{l}{ }^{\mathrm{v}} \mathrm{E}_{\text {shelf }} \\
\text { (J) }\end{array}$ & ${ }_{v} \alpha$ & $\begin{array}{l}{ }_{v} \mathrm{~T}_{\mathrm{re}} \\
\left({ }^{\circ} \mathrm{C}\right)\end{array}$ \\
\hline \multirow{2}{*}{$\begin{array}{c}\text { SS400 } \\
(\text { Wシリーズ })\end{array}$} & フイトッ外中央部 & 126 & 160 & 163 & 0.0400 & -16.3 \\
\hline & フランジB/4部 & 155 & 157 & 164 & 0.0273 & -40.0 \\
\hline \multirow{2}{*}{$\begin{array}{l}\text { SN400B } \\
\left(B^{\prime} リ リ-ス^{\prime}\right)\end{array}$} & フイトット央部 & 80 & 142 & 177 & 0.0188 & 0.9 \\
\hline & フランジB/4部 & 76 & 154 & 164 & 0.0245 & -12.3 \\
\hline
\end{tabular}

v $E=\frac{{ }_{v} E_{\text {shelf }}}{2}\left\{1+\tanh _{v} \alpha\left(T-v T_{r e}\right)\right\}$

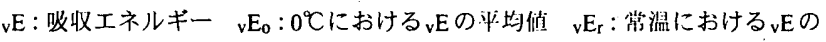

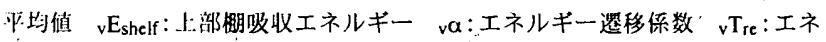
ルキー想移温度

る曲げ変形とせん断変形による弾性水平変位計算值 $\delta_{\mathrm{p}}(=20.8 \mathrm{~mm})$ を 基準として、弾性域 $, \pm 2 \delta_{\mathrm{p}}, \pm 4 \delta_{\mathrm{p}}, \pm 6 \delta_{\mathrm{p}}, \pm 8 \delta_{\mathrm{p}}$ の後、破断または油圧 ジャッキのストローク限界までの加力とした。 $\mathrm{R}$ 載荷は弾性域の載 荷の後 $\pm 6 \delta_{\mathrm{p}}$ を 10 回繰返し、その後破断または油圧ジャッキのスト ローク限界までの加力とした。 $\mathrm{R}$ 載荷は、基本載荷より簏しい荷重 条件下での接合部全体の力学性能を検討するために計画した。これ はW22-N及びB22-Nに基本載荷を行った結果、これらの試験体はい ずれも優れた力学性能を示し、補強の有無による力学性能の差違が 明確に現れないと推測したためである。

\section{3. 実験結果}

実験から得られた各試験体の梁端モーメントと梁の回転角の関係 を図 5 に示す。縦軸は試験体に作用する梁端モーメント $\mathrm{M}$ を素材試 験結果に基づく梁材の全塑性モーメント計算值 $\mathrm{M}_{\mathrm{p}}$ で除した值、横軸 は図 1 の変位計により加力点の変位から柱材の変形による回転角を 除いた梁の部材角 $\theta$ である。ここで、梁端モーメントMは柱面での 值を示し、図中 $\nabla \Delta$ は正負それぞれの載荷時におりる最大耐力点を、 $\boldsymbol{\nabla \Delta}$ は破断点を示している。また、基本載荷を行った試験体で崩壊 形式が局部座届であったものに関しては、荷重が最大耐力の $90 \% に$ 低下した点をマで示している。

各試験体の実験経過を載荷方法毎に以下に示す。基本載荷を行っ た試験体については、いずれも $88 \delta_{\mathrm{p}}$ を越えた最終載荷時に終局状態 に達し、終局時には全試験体で圧縮側梁フランジと梁ウェブに局部 座屈が観察された。崩壊モードについては、W39-N, W29-N及びB29$\mathrm{N}$ はスカラップ底を起点として引張側梁フランジ母材が延性破断を 生じた。また、これらの試験体では梁ウェブ接合部分にも破断が見 られ、梁ウェブ溶接端部を起点としてW39-N 及び W29-Nは梁ウェ ブ溶接金属で、B29-N はガセットプレート溶接端部の柱スキンプ レート側ボンド部で破断を生じた。これに対し、梁ウェブ接合部分 を補強した HD, VS 及び柱の幅厚比の小さいW22-N，B22-N は、ス カラップ底及びエンドタブスリット部に亀裂を生じたものの破断ま で進展することはなく、梁フランジ及び梁ウェブの局部座屈により 耐力低下を示し終局に至った。

$\mathrm{R}$ 載荷を行った試験体については、全試験体で 3 5 回目の $\pm 6 \delta_{\mathrm{p}}$ の 繰返し載荷時にスカラップ底とエンドタブスリット部に亀裂を生じ、 終局時には圧縮側梁フランジと梁ウェブに局部座屈が観察された。 図6に正加力時における繰返し回数に伴う各サイクル毎の最大耐力 の変動状況を示す。全試験体とも $-6 \delta_{\mathrm{p}}$ の 4 回目から前サイクルに比 べ最大耐力が低下し、繰返し回数の進行と共に耐力低下を示した。 W22について、Nは-6 $\delta_{p}$ の 5 回目にスカラップ底を起点として引張 側梁フランジ母材が延性破断を生じた。これに対し、梁ウェブ接合 

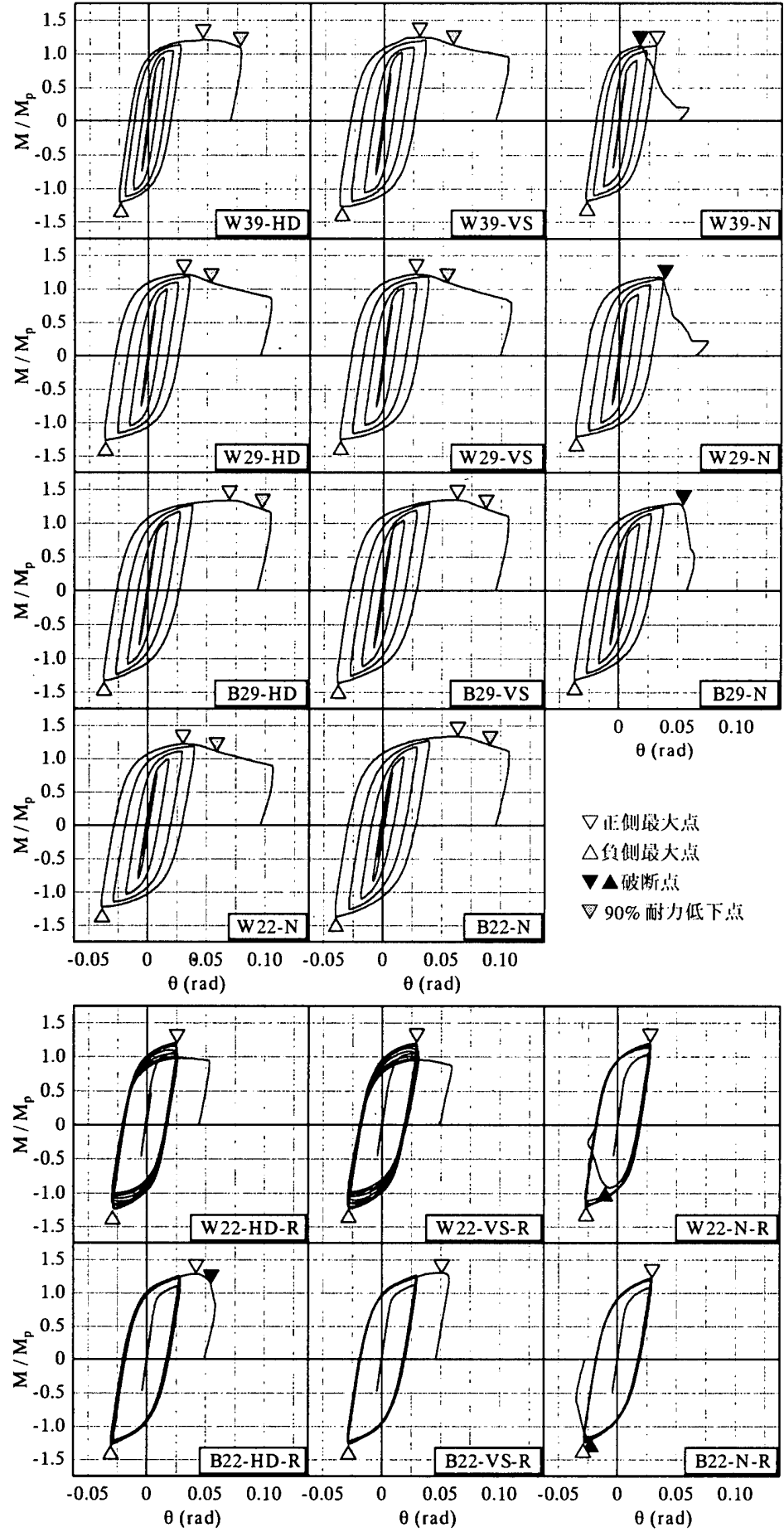

図 5 荷重一変形関係

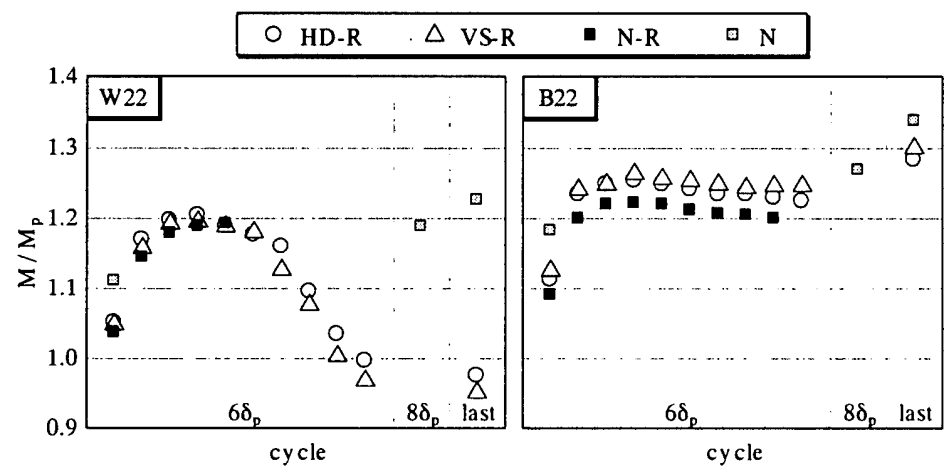

図 6 繰返し回数に伴う最大耐力の変動状況
部分を補強した試験体に関しては、繰返し回数の進行と共に 耐力低下を示したものの、最終載荷時まで破断を生じること なく梁フランジ及び梁ウェブの局部座屈により終局に至った。 B22では全試験体とも $\pm 6 \delta_{\mathrm{p}}$ の繰返し載荷中に若干耐力の隇少 が見られたものの、その後の耐力低下はあまり顕著ではない。 最終的にNは $-6 \delta_{\mathrm{p}}$ の 9 回目にエンドタブスリット部を起点と して引張側梁フランジ母材が延性破断を生じた。梁ウェブ接 合部分を補強した試験体に関しては、一定振幅繰返し載荷後 の最終載荷時にHDはエンドタブスリット部を起点として引張 側梁フランジ母材が延性破断を生じ、VSは梁フランジ及び梁 ウェブの局部座屈により耐力低下を示し終局に至った。

最終的に HD 及びNの全ての試験体で梁ウェブ接合部分周 辺において柱スキンプレートの面外変形が見られたが、その 程度はNに比べHDの方が小さくVSでは目視により確認する ことができなかった。また、Bシリーズの全試験体の高力ボル 卜摩擦接合部分において、 $-4 \delta_{\mathrm{p}} \sim+6 \delta_{\mathrm{p}}$ 時にガセットプレート と梁ウェブの間で迄りが生じたことが目視により認められた。 なお、溶接部の内部欠楩に関しては超音波探傷検査を行い全 試験体とも合格となっている。

\section{4. 柱梁接合部の力学性能}

基本載荷を行った試験体について、荷重一変形関倸履歷か ら求めた正加力側の骨格曲線を図7に示す。ここで、崩壊形式 が破断であった試験体については破断が生じた時点を、梁材 の局部座屈により耐力低下を示した試験体については最大耐 力の $90 \%$ まで耐力が低下した時点を終局とし、それぞれ終局 点から初期弾性剛性実験値で除荷したものである。また、縦 軸は図 5 と同様に $\mathrm{M} / \mathrm{M}_{\mathrm{p}}$ であり、横軸は梁の部材角 $\theta$ を $\mathrm{M}_{\mathrm{p}}$ に 対応する梁部材のみの曲げ変形とせん断変形による部材角計 算値 $\theta_{\mathrm{p}}(=\mathrm{W}: 0.00795 \mathrm{rad}, \mathrm{B}: 0.00759 \mathrm{rad})$ で除した值である。

各試験体の主要な実験結果一覧を表 5 に示す。ここで、 $\mathrm{eM}_{\mathrm{y}}$ は骨格曲線において接線剛性が初期弾性剛性実験值の $1 / 3$ とな る時の降伏曲げモーメント実験值、 $\mathrm{e}_{\max }$ は最大曲げモーメン 卜実験值、 $\alpha$ は $\mathrm{M}_{\max }$ を $\mathrm{M}_{\mathrm{p}}$ で除した最大耐力上昇係数、 $\mathrm{E} \eta_{\mathrm{s}}$ は 骨格曲線で囲まれた部分の面積を $\mathrm{M}_{\mathrm{p}} \cdot \theta_{\mathrm{p}}$ で除した塑性変形倍 率、 $\eta_{\mathrm{A}}$ は全載荷時の履歴曲線で曲まれた部分の面積の総和を

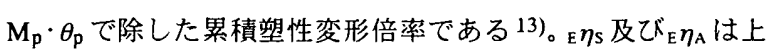
記の終局点までの値とした。以下、 ${ }_{\mathrm{e}} \mathrm{M}_{\mathrm{y}} / \mathrm{M}_{\mathrm{p}}, \alpha$ 及び ${ }_{\mathrm{E}} \eta_{\mathrm{s}}$ は終局 を迎えた正加力側における值を、 $\eta_{\mathrm{A}}$ は正加力側における值と 負加力側における值の和を性能指標とし、各実験変数が接合 部全体の力学性能に与える影響についての考察を述べる。

\section{1 補強形式及び柱の幅厚比の影響}

基本載荷を行った試験体について、 ${ }_{\mathrm{e}} \mathrm{M}_{\mathrm{y}} / \mathrm{M}_{\mathrm{p}}, \alpha$ 及で ${ }_{\mathrm{E}} \eta_{\mathrm{S}}$ と柱 の幅厚比 D/t の関係をそれぞれ図 8 10 に示す。図7とこれら の図から同一の D/t で無補強の $\mathrm{N}$ と補強された HD, VSを比 較すると、全てのシリーズにおいて明らかに HD, vs の方が 耐力, 塑性変形能力共に優れており、 $\mathrm{N}$ は崩壊形式が延性破 断であったのに対し HD, VSは局部座届であることからも、梁 ウェブ接合部分を補強することで接合部全体の力学性能の向 上が期待できると言える。降伏耐力でその差が顕著であり、全 


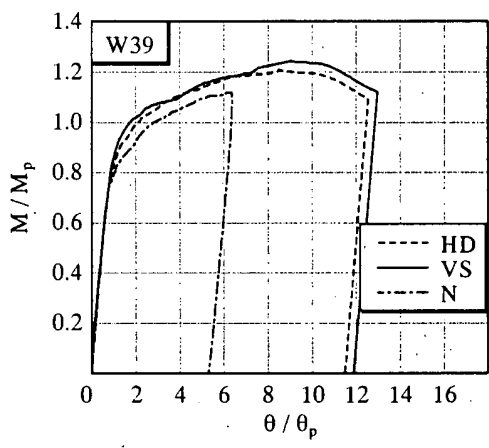

表 5 主要な実験結果一筧

\begin{tabular}{|c|c|c|c|c|c|c|c|c|c|c|c|c|c|c|}
\hline \multirow[t]{2}{*}{ 試験体名 } & \multirow[t]{2}{*}{$\begin{array}{c}{ }_{e} \mathrm{M}_{\mathrm{y}} \\
(\mathrm{kNm})\end{array}$} & \multicolumn{2}{|c|}{$\begin{array}{c}{ }_{e} \mathrm{M}_{\max } \\
(\mathrm{kNm})\end{array}$} & \multicolumn{2}{|c|}{${ }_{\mathrm{e}} \mathrm{M}_{\max } / \mathrm{M}_{\mathrm{u}}$} & \multirow{2}{*}{$\begin{array}{c}\text { 崩壊 } \\
\text { モ一ド } \\
{ }^{*} 1\end{array}$} & \multirow{2}{*}{$\begin{array}{c}\text { 破断 } \\
\text { 起点 } \\
* 2\end{array}$} & \multirow[t]{2}{*}{$\mathrm{e}_{\mathrm{y}} / \mathrm{M}_{\mathrm{p}}$} & \multicolumn{2}{|c|}{$\alpha$} & \multicolumn{2}{|c|}{${ }_{\mathrm{E}} \eta_{\mathrm{S}}$} & \multicolumn{2}{|c|}{$\mathrm{E} \eta_{\mathrm{A}}$} \\
\hline & & + & - & + & - & & & & + & - & + & - & + & - \\
\hline W39-HD & 540 & 797 & 792 & 1.07 & 1.06 & 0 & - & 0.8 .19 & 1.21 & 1.20 & 12.9 & 5.1 & 18.7 & -8.9 \\
\hline W39-VS & 583 & 820 & 837 & 1.10 & 1.12 & 0 & - & 0.885 & 1.24 & 1.27 & 13.7 & 8.2 & 21.3 & 14.1 \\
\hline W39-N & 490 & .737 & 779 & 1.05 & 1.11 & $x$ & A & 0.744 & 1.12 & 1.18 & 5.4 & 6.2 & 11.6 & 10.3 \\
\hline W29-HD & 569 & 801 & 835 & 1.07 & 1.12 & 0 & - & 0.864 & 1.22 & 1.27 & 11.8 & 8.0 & 19.7 & 13.5 \\
\hline W29-VS & 602 & 804 & 829 & 1.08 & 1.11 & 0 & - & 0.914 & 1.22 & 1.26 & 12.9 & 8.5 & 20.6 & 14.2 \\
\hline W29-N & 518 & 776 & 798 & 1.09 & 1.12 & $x$ & A & 0.786 & 1.18 & 1.21 & 8.8 & 7.7 & 16.5 & 13.4 \\
\hline W22-N & 529 & 807 & 809 & 1.11 & 1.11 & 0 & - & 0.803 & 1.23 & 1.23 & 13.2 & 8.1 & 22.0 & 14.6 \\
\hline B29-HD & 552 & 840 & 840 & 1.04 & 1.04 & $\mathrm{O}$ & - & 0.878 & 1.33 & 1.33 & 18.0 & 7.2 & 28.6 & 14.1 \\
\hline B29-VS & 579 & 846 & 860 & 1.05 & 1.07 & 0 & - & 0.920 & 1.34 & 1.37 & 16.3 & 7.8 & 28.2 & 15.5 \\
\hline B29-N & 515 & 812 & 829 & 1.07 & 1.09 & $x$ & A & 0.818 & 1.29 & 1.32 & 10.0 & 7.1 & 20.2 & 14.1 \\
\hline B22-N & 538 & 842 & 865 & 1.08 & 1.11 & $\mathrm{O}$ & - & 0.855 & 1.34 & 1.37 & 17.8 & 8.1 & 28.9 & 15.8 \\
\hline "W22-HD-R & (586 & 793 & "818 & 1.06 & 1.09 & $\bar{O}$ & 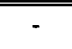 & 0.890 & 1.20 & 1.24 & 6.2. & 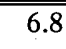 & 34.2 & 32.6 \\
\hline W22-VS-R & 591 & 786 & 811 & 1.05 & 1.08 & 0 & - & 0.897 & 1.19 & 1.23 & 6.9 & 7.4 & 35.7 & 28.7 \\
\hline W22-N-R & 521 & 783 & 789 & 1.07 & 1.08 & $x$ & A & 0.791 & 1.19 & 1.20 & 6.5 & 6.6 & 20.5 & 21.6 \\
\hline B22-HD-R & 557 & 807 & 779 & 1.00 & 0.97 & $x$ & $\mathrm{~B}^{\prime}$ & 0.885 & 1.28 & 1.24 & 10.5 & 6.1 & 57.0 & 48.0 \\
\hline B22-VS-R & 561 & 818 & 798 & 1.01 & 0.99 & 0 & - & 0.892 & 1.30 & 1.27 & 10.3 & 5.9 & 58.0 & 49.7 \\
\hline B22-N-R & 517 & 769 & 784 & 0.99 & 1.01 & $x$ & B & 0.821 & 1.22 & 1.25 & 5.2 & 5.8 & 39.9 & 43.0 \\
\hline
\end{tabular}

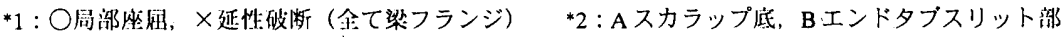

シリーズともそれぞれ $\mathrm{N}<\mathrm{HD}<\mathrm{VS}$ の順に $\mathrm{e}_{\mathrm{y}} / \mathrm{M}_{\mathrm{p}}$ の值が

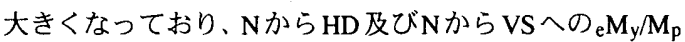
の值の増加量はD/tの値の大小に関わらずほぼ同程度と なっている。最大耐力及び塑性変形能力では、W39の 方がW29に比べ補強による接合部全体の力学性能の向 上が著しく、柱スキンプレートの面外剛性が低い場合 には梁ウェブ接合部分の補強効果が大きいことがわか る。また、 $\mathrm{R}$ 載荷を行った試験体について $\alpha$ と $\eta_{\mathrm{A}}$ の関 係を図11に示す。図6及び図 11 から、W22,B22 共にN よりもHD, VSの方が各サイクルにおける最大耐力, $\alpha$ 及び $\eta_{\mathrm{A}}$ の值が大きくなっていることがわかる。最大耐 力の変動状況は補強の有無に関わらず同様の傾向を示 しているが、無補強の $\mathrm{N}$ は補強試験体に比べ小さな繰 返し数で延性破断による終局を迎えている。これらの ことから、D/tが小さい場合でもより箃しい荷重条件の もとでは、梁ウェブ接合部分の補強による最大耐力及 び塑性変形能力の向上を期待できると言える。

次に、 $\mathrm{D} / \mathrm{t}$ の変化に伴う接合部全体の力学性能の差違 に関して考察する。図7 10において無補強のNについ て見ると、D/tの值が小さくなるにつれて耐力, 塑性変 形能力共に大幅に上昇する傾向にある。補強を行った

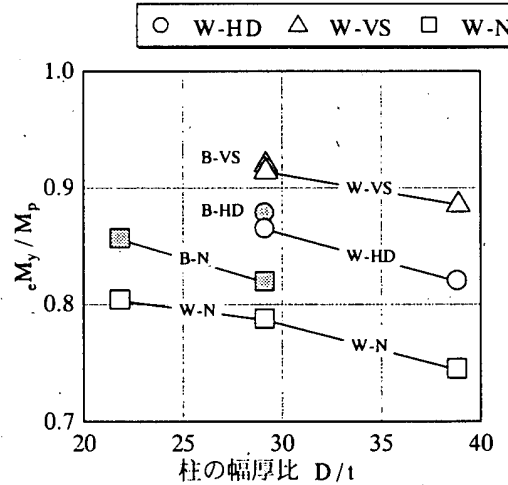

図 $8 \quad \mathrm{eM}_{\mathrm{y}} / \mathrm{M}_{\mathrm{p}}-\mathrm{D} / \mathrm{t}$ 関係

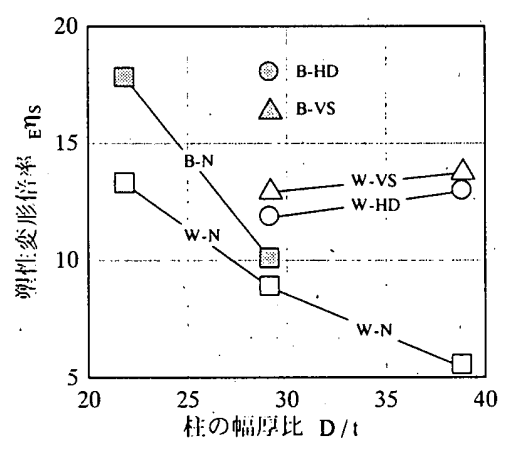

図 $10 \quad \mathrm{E} \eta_{\mathrm{S}}-\mathrm{D} / \mathrm{t}$ 関係

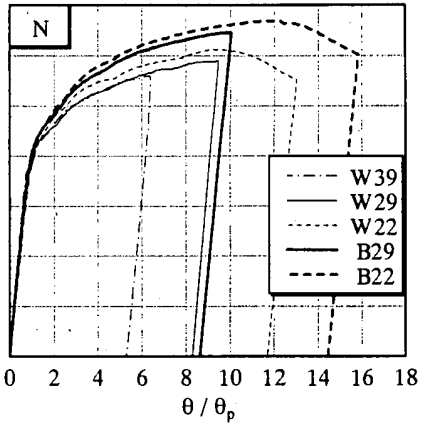


試験体に関しては、W39及びW29の補強試験体はW22-N と、B29の 補強試験体はB22-N と同程度或いはそれ以上の力学性能を示してい る。D/tが39，29という幅厚比が大きい柱材を用いた接合部でも、梁 ウェブ接合部分を補強することにより梁ウェブに積極的に曲げを負 担させることができたため、接合部の最大耐力は梁部材の局部座届 によって限界付けられ、試験体全体の力学性能は梁自身の性能で決 まっていることがわかる。これらのことから柱の幅厚比は柱梁接合 部の力学性能に大きく影響を及ぼし、梁端接合部での破断を避ける ために柱スキンプレートの面外剛性を確保することの必要性を改め て確認することができた。なお、W39 と W29 を比較すると NはD $/ \mathrm{t}$ の値が大きくなるにつれて $\alpha$ 及び $\eta_{\mathrm{s}}$ の值が減少する傾向にあるのに 対し、VSでは $\alpha$ 及び $\eta_{\mathrm{S}}$ の值が、HD では $\eta_{\mathrm{S}}$ の值が $\mathrm{D} / \mathrm{t}$ の值の増加 に伴って僅かに上昇している。ただし、この上昇の程度は極めて小 さく実験値のばらつきの範囲内であると考えられ、これらの試験体 が梁部材の局部座屈によって終局に至った結果によるものであると 考えられる。

\section{2 梁端接合形式及び材料特性の影響}

接合形式及び材料特性の違いに関して、図 7 10において同一の D/t であるW29 とB29，W22 とB22について補強形式が同じ試験体を比 較すると、降伏耐力, 最大耐力及び塑性変形能力全てにおいて B シ リーズの方が優れた性能を示している。降伏耐力に関してW29 と B29を比較すると、W29-Nに比べB29-Nの方が明らかに大きくなっ ているのに対し、補強試験体はW29-HD とB29-HD、W29-VS とB29VSはほぼ同程度の値となっている。W22-R と B22-Rを比較した場合 にも同様の傾向が認められる。これは、無補強試験体では接合形式 の違いが柱スキンプレートの面外曲げ挙動に影響を与えていること を示唆しているものと考えられる。つまり、今回の B シリーズの試 験体の設計では梁ウェブからの応力をガセットプレートに十分伝達 させることを設計条件としたため降伏耐力時では高力ボルト摩擦接 合部分に过りが生じておらず、梁ウェブに比べ板厚の大きいガセッ トプレートを用いたことにより柱スキンプレートの補剛効果が生じ、 その結果降伏耐力が上昇したと考えられる。

最大耐力に関しては、梁フランジ材の降伏比の影響であることは明 らかである。梁フランジの曲げ挙動が単純引張に近い状態である場合 には、降伏比の逆数が耐力上昇率となる。Wシリーズに用いた梁フ ランジ材の降伏比は71\%であるのに対し、Bシリーズに用いたものの それは $66 \%$ であり、W シリーズと B シリーズの比は約 1.07 である。 表 5 においてD/t及び補強形式が同じ試験体の赛験結果を比較すると ほぼこの比の值に対応する結果となっており、梁フランジ材の降伏比 は接合部全体の最大耐力に大きく影響を及ぼすことがわかる。

塑性変形能力に関しては、梁フランジ材の降伏比及びガセットプ レートによる梁ウェブの座屈拘束の影響が考えられる。梁フランジ 材の降伏比は、最大耐力の上昇だけでなく部材の塑性化領域㹡大に 寄与し、降伏比が低い方が部材の長手方向に塑性化が広がるため塑 性変形能力に優れていることが報告されている14)。Bシリーズの方 が降伏比が低いことからより優れた塑性変形能力を示したと考えら れる。また、高力ボルト摩摖接合部分ではガセットプレートが梁 ウェブの局部座届を拘束しているために梁フランジの塑性化領域が

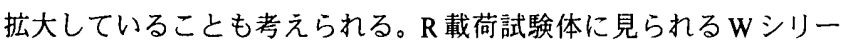
ズと Bシリーズの耐力変動の違いもこれらの影響であり、梁フラン
ジ材の降伏比及び梁ウェブ端部支持条件は局部座屈耐力及びその発 生時期に影響を及ぼすと考えられるが、本研究の範囲では推察に過 ぎずこれらの点の解明は今後の課題である。

なお、Bシリーズの実験結果には高力ボルト摩擦接合部分におけ るガセットプレートと梁ウェブの过りによる回転量が含まれている が、これは最大（高力ボルトとボルト孔のクリアランス $2 \mathrm{~mm}$ 分が完

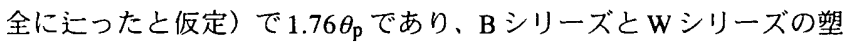
性変形能力の大小関係が逆転する程の影響を及ぼすものーではない。 ただし、この部分の过りによる梁端部の回転は梁フランジの累積歪 を増加させることから、下フランジを内側から溶接している一般的 な梁端混用接合部では梁フランジでの破断を生じ易い。これを回避 するために、今回の B シリーズの試験体では梁フランジ溶接部の ルート部を内側としていることを改めて記しておく。

\section{5. 梁端接合部周辺の歪性状}

梁ウェブ接合部分の補強効果及び柱の幅厚比の影響を詳紐に検討す るため正加力時の梁端部周辺の歪分布状況を見る。ここで、各歪の值 はスケルトン歪を用いた。各部における歪測定位置を図 12に示す。

梁ウェブ接合部分周辺の柱面の歪性状に関して、図12に示す柱面 $\mathrm{A}, \mathrm{B}, \mathrm{C}$ 点における歪量 $\left|\varepsilon_{1}-\varepsilon_{2}\right|\left(\varepsilon_{1}, \varepsilon_{2}\right.$ : 主歪) の分布状況を図 13,14 に示す。図13 は最も大きな補強効果が確認されたW39について補 強形式毎に示したものであり、それぞれ梁の部材角が $0.5,1,2,4 \theta_{\mathrm{p}}$ 時のものを示している。この図から、Nはダイアフラムに近いC 点 に歪が集中し値が大幅に大きくなっているのに対し、HD, VSは比 較的広い範囲に歪が分布し歪量も小さくなっていることがわかる。 この分布形状の違いは梁の変形が進むにつれて顕著になり、B, C点 での歪量は $\mathrm{VS}<\mathrm{HD}<\mathrm{N}$ の順に大きくなっている。このことから、梁 ウェブ接合部分の補強により柱スキンプレートの局所的な変形を抑 制することができ、面外への変形量が柱面の比較的広い範囲で一様 になると言える。また HD とVS を比較すると、歪量及び実験時にお ける変形量の観察結果からVSの方が面外変形を抑制していることが わかる。これらの補強形式による歪分布形状及び歪量の違いは、值 の大小はあるもののW39だけでなく全てのシリーズで同様の傾向が 確認されている。また、梁ウェブ接合部分を補強した試験体では梁 の変形が進むにつれて歪量の増加の割合がほぼ一定となるのに対し
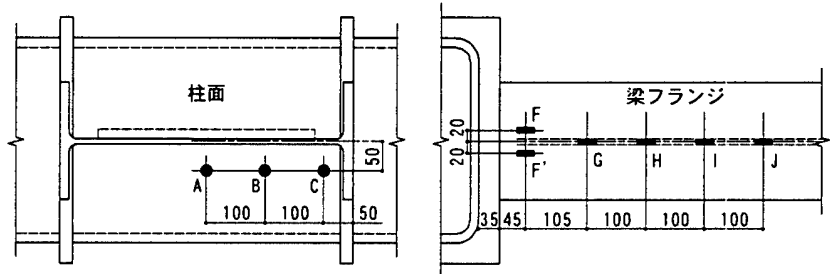

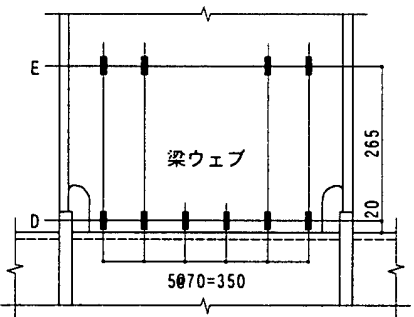

Wシリーズ梁ウェフ

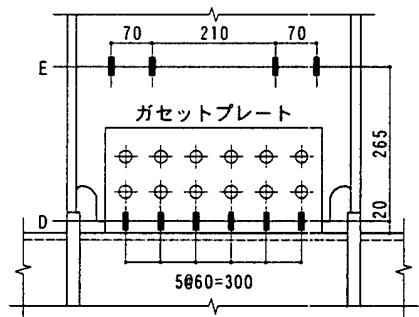

Bシリーズガセットプレート
図 12 梁端接合部周辺におけるゲージ貼付位置 
て、無補強の試験体では梁の変形に伴い歪量の増加の割合が著しく

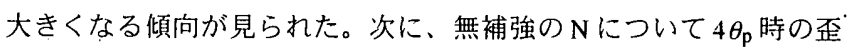
分布状況を図 14 に示す。柱の幅厚比が大きくなるにつれてC点での 丕量が増加していることから、D/tの増大により局所的な面外変形が 大きくなることが明らかである。

梁ウェブ接合部分の歪性状に関して、図 12 に示すD断面における 歪分布状況を図 15 に示す。ここで、歪の值は図 13 の柱面歪量分布 において補強形式による歪分布形状に明確な違いが見られ始めた $2 \theta_{\mathrm{p}}$ 時のものであり、ゲージ貼付位置はWシリーズで梁ウェブ、Bシリー ズでガセットプレートとなっている。この歪分布形状を見ると、無 補強のNは両端部のみ他の測定位置に比べ歪が幾分大きな值を示し ている。これに対し、補強を行った HD, VS では両端部の広い領域 でほぼ三角形に歪が分布しており広い範囲で曲げ応力を伝達してい ることが認められる。また、歪の值を比較すると全測定位置におい てNに比べHD, vSの方が大きくなっている。これらのことから、梁 ウェブの取付く柱内部の補強により柱スキンプレートの面外剛性を 確保することで梁ウエブ接合部分の曲げ応力の伝達範囲が広がりそ の応力負担量が大きくなった結果、梁ウェブ接合部分の負担曲げ耐 力が上昇する状況が推察される。このことは、補強形式が同じ試験
体を比較した場合に $\mathrm{D} / \mathrm{t}$ の減少に伴って各測定位置での歪が大きく なっていることからも確認できる。

次に、梁端接合形式及び材料特性の違いによる影響を検討する。 図 12 に示す $\mathrm{E}$ 断面における歪分布状況を図 16 に、引張側梁フラン ジ外面の中央部における材軸方向の歪分布状況を図17に示す。ここ で、図 17，における梁端部 $\mathrm{F}$ 点の歪の值は図 12 に示す $\mathrm{F}, \mathrm{F}$ 点の 2 枚 の歪ゲージによる測定値の平均值であり、図 16,17 共に $6 \theta_{\mathrm{p}}$ 時のも

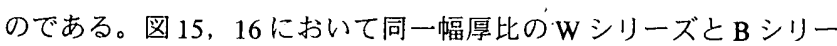
ズを比較すると、歪の值はWシリーズに比ベBシリーズの方が全体 的に小さくなっている。この要因に関しては：梁ウェブ材軸方向の 歪性状なども関連すると考えられるため断定することはできないが、 $6 \theta_{\mathrm{p}}$ 時における差は、 $\mathrm{B}$ シリーズでは高力ボルト摩擦接合部分でガ セットプレートと梁ウェブの間で迄りが生じたことにより、溶接接 合としたWシリーズに比べ梁ウェブから柱面への応力伝達効率が若 干低下したためであると考えられる。補強効果に関しては、図16に おいてW29 とB29 を比較すると、HD, VS それぞれの歪分布形状に は違いは見られないが、Nに対する補強試験体の歪の増加量はW シ リーズの方が大きくなっている。このことは、無補強の $\mathrm{N}$ を比較し た場合、 D/t の減少に伴う歪の増加量が B シリーズに比ベ W シリー
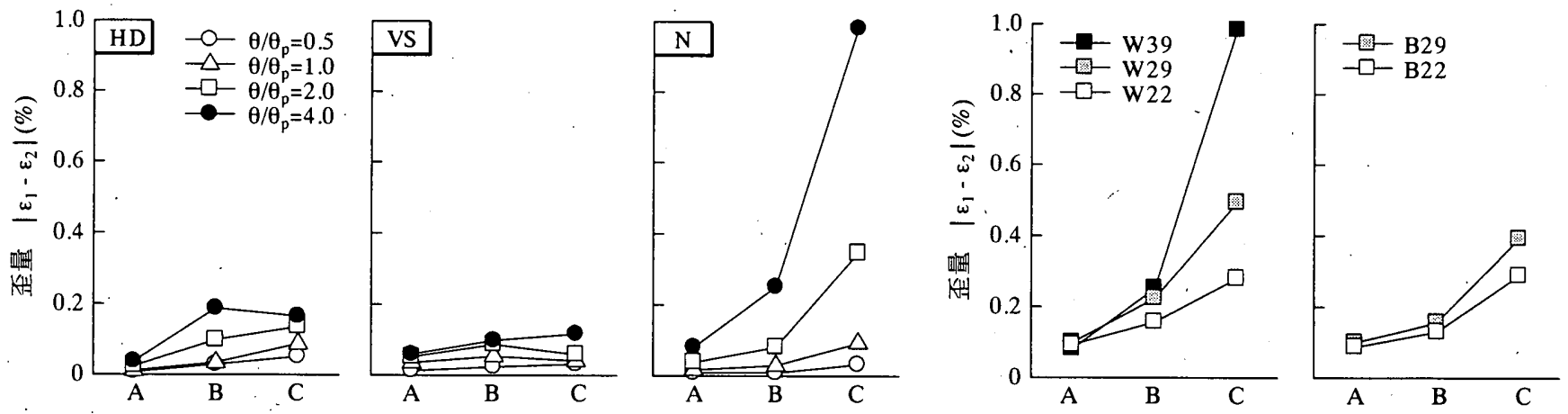

図 13 W39 の柱面における歪量分布
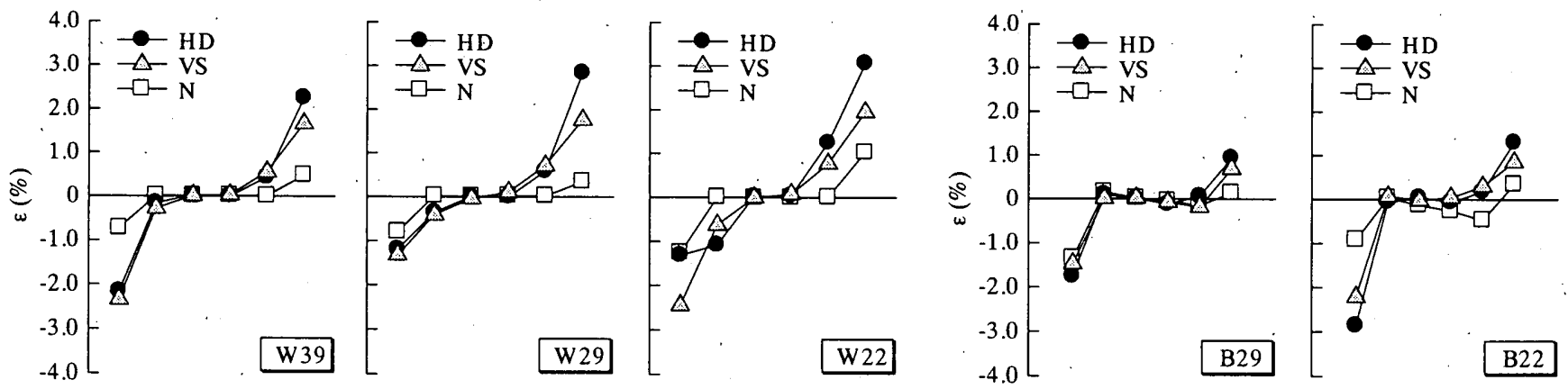

図 15 梁ウェブ D 断面における歪分布（ $2 \theta_{\mathrm{p}}$ 時）

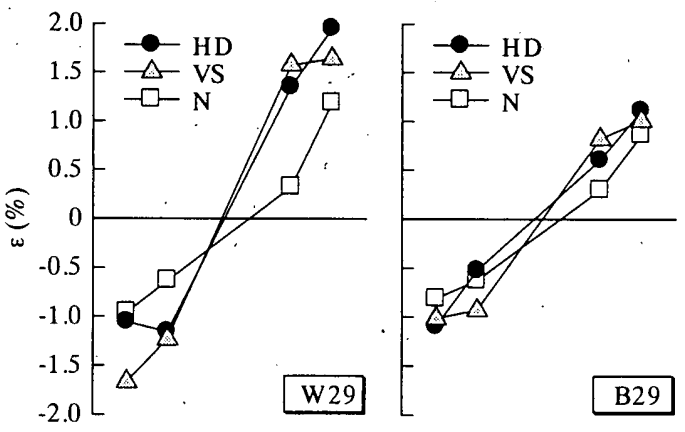

図 16

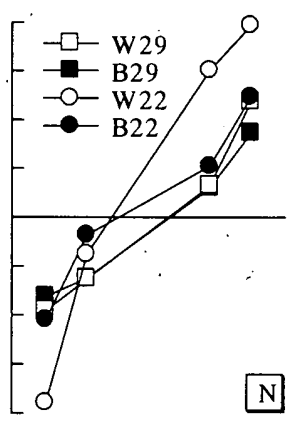

$\mathrm{N}$
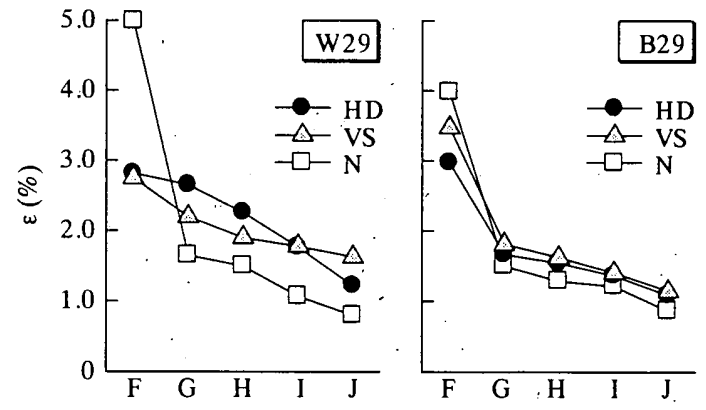

図 17 梁フランジ材軸方向の歪分布 (6 $\theta_{\mathrm{p}}$ 時) 
ズの方が大きくなっていることからも確認できる。一方、梁フラン ジ外面の材軸方向の歪分布形状に関しては、無補強の $\mathrm{N}$ を比較する とWシリーズは梁端部 $\mathrm{F}$ 点での值が他の測定位置に比べ大きな值を 示しており、この部分に大きな歪集中が見られる。これに対し B シ リーズでは F点での歪はW シリーズのものよりも小さく、分布形状 も部材の長手方向にやや緩やかに分布している。これらのことから、 前述したBシリーズの方がWシリーズに比ベ優れた力学性能を示し ている点は、梁フランジの塑性化領域が部材の長手方向に広がって いることが要因であることが推定でき、梁フランジ材の降伏比及び ガセットプレートによる梁ウェブの局部座屈拘束効果とも関連して いると考えられる。補強効果に関しては、F点での歪はNに比べHD, VSの方が小さくその他の測定位置ではNに比べHD, VSの方が大き くなっていることから、補強により梁ウェブの曲げ負担量が増加す ることで梁フランジ端部への歪集中が緩和され、梁フランジの塑性 化領域が広がっている状況が認められる。補強による梁フランジに おける塑性化領域の広がりの程度は、梁ウェブの曲げ負担範囲の場 合と同様、B シリーズに比ベ W シリーズの方が大きくなっている。

補強形式の違いに関しては、総合的に判断するとVSの方が接合部 全体の力学性能に優れている。しかし、その差は僅かなものであり 両補強形式ともほぼ同程度の力学性能が得られることから、様々な 状況に応じて選択が可能であると言える。本研究の範囲内では、柱 の幅厚比が22程度以下であれば無補強であっても優れた接合部性能 が得られ、D/tがそれより大きい場合でも補強工法を用いることで $\mathrm{D} / \mathrm{t}$ が 22 のものと同等或いはそれ以上の力学性能が期待できる結果と なっている。補強工法の採用にあたっては、VS補強形式では梁ウエ ブと同一平面内に補強縦スチフナを配置し、HD補強形式では柱スキ ンプレートの面外変形を抑制するために梁ウェブ接合部分における 曲け負担範囲を考虑して適切な位置に配置することが重要である。

\section{6. 結 論}

本研究では、鋼構造柱梁接合部の梁ウェブが取付く柱内部を補強 し梁ウェブに積極的に曲げを負担させることにより接合部全体の耐 力，塑性変形能力を向上させることを目的として、水平ダイアフラ ム補強形式と縦スチフナ補強形式を用いた場合について実大加力実 験を行った。実験結果から、梁ウェブ接合部分の補強形式, 柱の幅 厚比及び梁材の鋼種の違いが梁端接合部の力学性能に与える影響を 把握することができた。なお、梁端接合形式の影響に関しては今回 の実験の範囲では明確な差は認められなかった。本研究により明ら かとなった主な点をまとめると以下のようになる。

1）柱スキンプレートの面外㓮性は試験体（部分架構）全体の力学性 能に大きく影響を及ぼし、柱の幅厚比が小さくなるにつれて試験 体の耐力及び塑性変形能力は上昇する。

2）梁ウェブ接合部分を補強することの効果は以下の通りである。

・崩塄モ一ドが梁端部における延性破断から梁材の局部座屈となり、 試験体 (部分架構) の耐力及び塑性変形能力は向上する。その効 果は柱スキンプレートの面外剛性が低い程大きい。

・柱スキンプレートの面外剛性が高まり、梁ウェブからの曲げ応力 の伝達領域が広がる。これにより梁ウェブ接合部分の応力負担量 が大きくなり、梁ウェブ接合部分の曲げ耐力が上昇する。

・柱スキンプレートの局所的な変形が抑制され面外への変形量が柱
面の比較的広い範囲で一様になる。なお、水平ダイアフラム補強 に比べ縦スチフナ補強の方が面外変形を抑制する効果は大きい。

3）梁フランジ材の降伏比は接合部全体の最大耐力及び塑性変形能力 に大きく影響を及ぼし、降伏比が低い場合程試験体 (部分架構) の 最大耐力及び塑性変形能力は向上する。

\section{謝 辞}

本研究は文部省科学研究費補助金・基盤研究(C)(2)(課題番号 : 11650576, 研究代表者: 田中淳夫）の補助を受けた。また、実験の 実施に際しては田中研究室に当時在籍していた多くの学生の協力を 戴いた。特に本実験の担当であった大学院生の平井弘毅君，卒論生 の阿部茂君及び村田学君には多大な協力を戴いた。これら関係各位 に深く感謝の意を表す。

\section{参考文献}

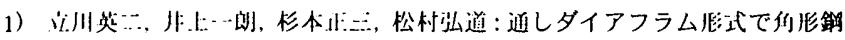

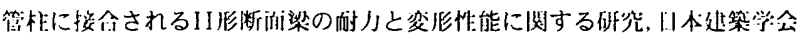

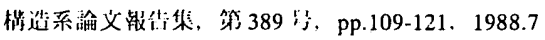

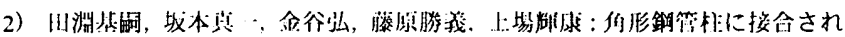

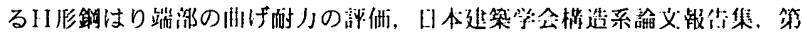
389 ' 13 , pp.122-131, 1988.7

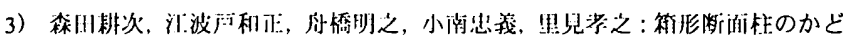

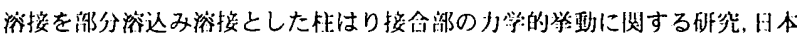

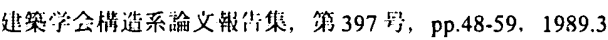

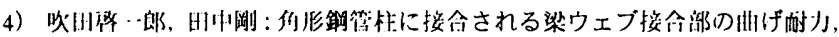

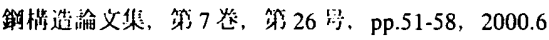

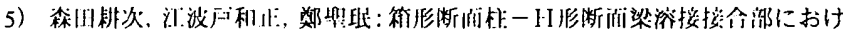

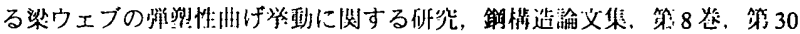
浨, pp.51-66, 2001.6

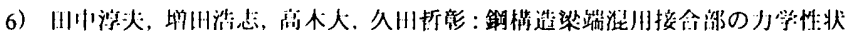

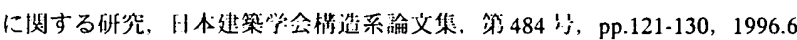

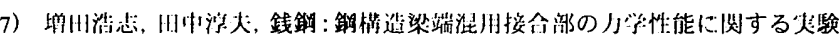

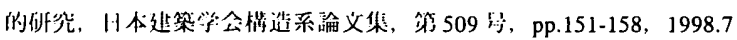

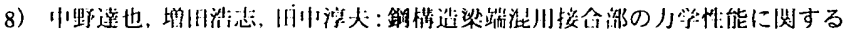

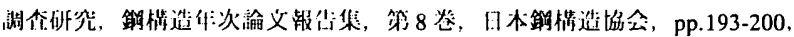
2000.11

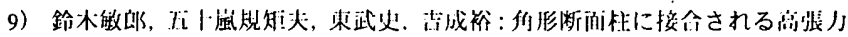

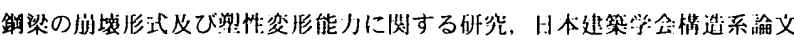
集, pp.133-140, No.517, 1999.3

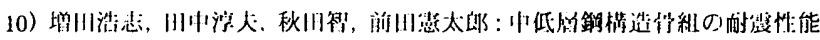

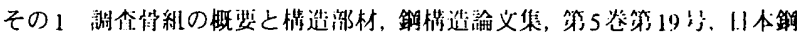
槛造治会. pp.65-72, 1998.9

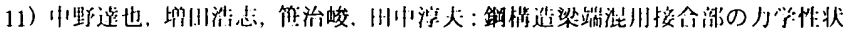

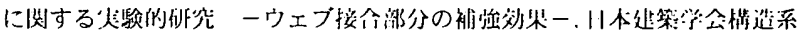
湔文集，pp.139-144， No.556，2002.6

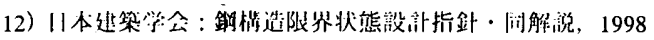

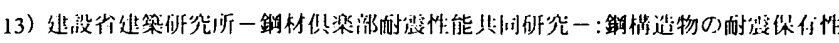

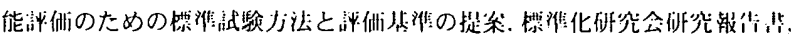
1994.12

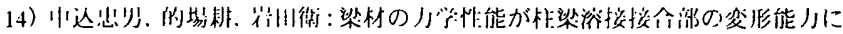

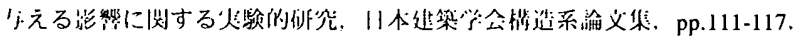
No.540, 2001.2

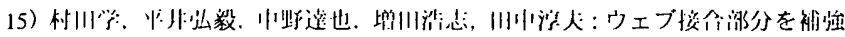

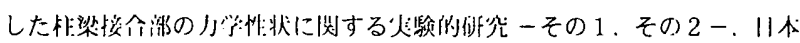

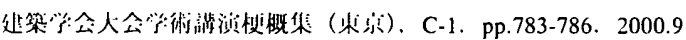

（2002年 8 月 22 日原稿受理，2003年 1 月 31 日採用決定） 